\title{
A VASSALAK MARADVÁNYOK ARCHEOMETALLURGIAI JELENTŐSÉGE
}

\section{ARCHAEOMETALLURGICAL IMPORTANCE OF IRON SMELTING AND SMITHING SLAGS}

\author{
Nyulas Dorottya ${ }^{1}$, Bitay Enikő ${ }^{2}$, Kacsó Irén $^{3}$, Manciula Dorin ${ }^{4}$, Veress Erzsébet ${ }^{5}$ \\ ${ }^{1}$ Babes-Bolyai Tudományegyetem, Történelem és Filozófia Kar, Magyar Történeti \\ Intézet, Régészeti és Müvészettörténeti Tanszék, 400088 Romania, Cluj, Napoca 11, \\ Tel. +40-264-405300-5275, Fax: +40-264-405326, nydorottya@yahoo.com
}

${ }^{2}$ Sapientia Erdélyi Magyar Tudományegyetem, Marosvásárhelyi Müszaki és Humán Tudományok Kar,540485 Târgu-Mureş, O.p. 9, C.p. 4., Tel.+40-751-016063, ebitay@ms.sapientia.ro
${ }^{3}$ National Institute for Research and Development of Isotopic and Molecular Technologies INCDTIM, 400293 Romania, Cluj, Donath 67-103, OP 5 CP 700 Tel. +40 745-645670,iren.kacso@gmail.com
${ }^{4}$ Babes-Bolyai University, Faculty of Environmental Sciences and Engineering, Department of Environmental Analysis and Engineering, 400294 Romania, Cluj, Fantanele 30,Tel.+40-264-307030,dimro21@gmail.com
${ }^{5}$ Erdélyi Múzeum-Egyesület, 400750 Romania, Cluj/Kolozsvár, OP 1 CP 191, Tel. +40-743-119275, veresserzsebet@gmail.com

\begin{abstract}
Iron production slags from different stages of production (smelting and smithing) are mostly distinguished on the basis of their morphological characteristics. Where smithing and smelting slag morphologies are overlapping, they can be discriminated chemically. Assuming that the different slags are safely distinguished, they can be categorized according to their particular technological origins (i.e., bloomery furnace, blast furnace, puddling hearth, finery, smithy) and provenance. The systematics for grouping generally relies on the weight of interferences drawn from chemical, morphological, microstructural and contextual analysis. Correct interpretation of the archaeometallurgical data obtained on iron slags is mandatory in order to realize their correct clustering and reach a correct archaeological conclusion.
\end{abstract}

Keywords: archaeometallurgy, iron slags, morphological and chemical systematics

\section{Összefoglalás}

A vas kémiai reakcióképessége következtében a megfelelően azonosított vassalak maradványok adatszolgáltatóként kikerülhetetlenek mind a vasgyártás és vasmüvesség folyamatainak fizikai-kémiai és metallurgiai aspektusainak, mind a vasleletek származásának jellemzése szempontjából.

Az azonos kontextusból származó, régészeti sztratigráfiai szempontból koherens, adott kronológiai indikátorokkal jellemezhető vassalak maradványok feltehetően egyazon vasmüves rendszer azonos korú és származású leletei. Minden leletegyüttesen belül azonban tapasztalhatók kisebb-nagyobb eltérések, hiszen a minták származhatnak egy vagy több technológiai ciklus különböző szakaszaiból, a salakok szerkezete és összetétele heterogén, és különbözhetnek az egyes termelési ciklusok körülményei, akár a gyártási recept és eljárás is. 
A salakleletek helyes tipizálásának tehát nem lehet eltúlozni a jelentőségét a kohósítási technológiára, valamint a leletek provenanciájára vonatkozó megbízható régészeti következtetések szempontjából.

Kulcsszavak: archeometallurgia, vassalakok, morfológiai és kémiai csoportositás

\section{Bevezetés}

Az archeometallurgia célja müszaki anyagvizsgálat segítségével meghatározni a fém régészeti leletek elöállítási technológiáját, fizikai-kémiai és technikai paramétereit, sajátosságait. A vas archeometallurgiája esetében maga a lelet és a lelőhely mellett vizsgálni kell tehát a kohósításhoz szükséges, és a lelőhelyen vagy annak közelében talált alapanyagokat és segédanyagokat (érc, faszén, mészkő, dolomit), az ércelőkészítés során a helyszínen maradt anyagokat, a salakleleteket, a bucakohó helyszínén maradt feldolgozatlan vasbucát, a kovácsmühely bucamaradványait, és az esetleg ott maradt kovácsolt vastárgy maradványokat is [1].

A vas kémiai reakcióképességéből következő "sérülékenysége" miatt mind a vasgyártás és vasmüvesség folyamatainak fizikai-kémiai és metallurgiai aspektusairól, mind a vasleletek származásáról a megfelelően azonosított vassalak maradványok (bucasalak, ritkábban kovácssalak) szolgáltatják a legtöbb adatot.

Az azonos kontextusból származó, régészeti sztratigráfiai szempontból koherens, adott kronológiai indikátorokkal jellemezhető vassalak maradványok feltehetően egyazon vasmüves rendszer azonos korú és származású leletei, a leletegyüttesen belül azonban kisebbnagyobb eltérések tapasztalhatók. Egyrészt a salakdarabok származhatnak egy technológiai ciklus különböző szakaszából, és az azonos szakaszból származó salak szerkezete és összetétele is heterogén. Másrészt a különböző termelési ciklusok körülményei mindig különböznek. Végül a felhalmozódás alatt akár többször is változhatott a gyártási recept és eljárás. A salakleletek helyes tipizálásának tehát nagy a jelentősége [2].

\section{Vassalak típusok és jellemzőik}

A vasgyártás során keletkező bucasalak két fő típusának (folyósalak, kemencesalak) közös jellemzője a nagy $\mathrm{FeO}$ és $\mathrm{SiO}_{2}$ tartalom, az erősen savanyú jelleg és a fayalitos $\left(\mathrm{Fe}_{2} \mathrm{SiO}_{4}\right)$ ásványszerkezet, összetétel, szerkezet és szín alapján azonban általában könnyen megkülönböztethetők, osztályozásukat is rendszerint erre alapozzák [1].

A világosabb barnás-vörös, kisebb sürüségü, erösen tagolt, szivacsszerü kemencesalak a $\mathrm{SiO}_{2}$ és az általa lekötött jelentős mennyiségü $\mathrm{FeO} 1170{ }^{\circ} \mathrm{C}$ fölötti, fayalitként való elfolyása után a kemencében, a buca közelében marad (gyakran azt szennyezve). A vártnál általában nagyobb $\mathrm{Fe}_{2} \mathrm{O}_{3}$ tartalma a lassú kihülés során bekövetkező részleges reoxidációnak és az esetlegesen belekerült vasszemcsék időbeni rozsdásodásának eredménye.

A kemence elöterében levő salakgyüjtő gödörben található, 70-80 \%-ban fayalitoswüstites folyósalak jól átolvadt, gyakran feketén vagy fémesen csillogó felületü, nagy sürüségü üveges anyag, kisebbnagyobb gázbuborék zárványokkal. Reoxidáció a folyósalakok esetében is előfordul, nem ritka a $10 \%$ fölötti $\mathrm{Fe}_{2} \mathrm{O}_{3}$ tartalom.

A kovácstevékenység után általában kevés a salaknyom, a kohósítást befejező bucatömörítés nyomait pedig nehéz megkülönböztetni a kovácstüzhelyek salakjaitól. Mivel a buca tömörítésekor 
kipréselt, kovácsolásakor lepattant vasszilánkos kovácssalak voltaképp kemencesalak, nincs, nem is lehet tipikus, kizárólagosan jellemző külalakja. Kovácssalakként való azonosítását nagyobb $\mathrm{Fe}_{2} \mathrm{O}_{3}$ tartalma könnyítheti meg (a salakdarabokkal lepattant vasszegmensek az eltemetés ideje alatt természetes módon rozsdásodnak).

\section{Vassalakok csoportba sorolása}

A különböző vassalak mintákat első megközelítésben (bucasalak - kovácssalak, illetve kemencesalak - folyósalak) makroés mikromorfológiai szempontok szerint osztályozzák [2].

Szerkezetüket tekintve a salakok inhomogének (1. ábra). Mikroszerkezetük [1] az elektronmikroszkópos vizsgálatok szerint föként dendrites, néha táblás (poliéderes) kristályosodással, ritkán amorf állapottal, a fayalitos részeket $(\mathrm{Al}, \mathrm{Mg}, \mathrm{Ca})$ szilikátok több-kevesebb vasat tartalmazó ásványai veszik körül.

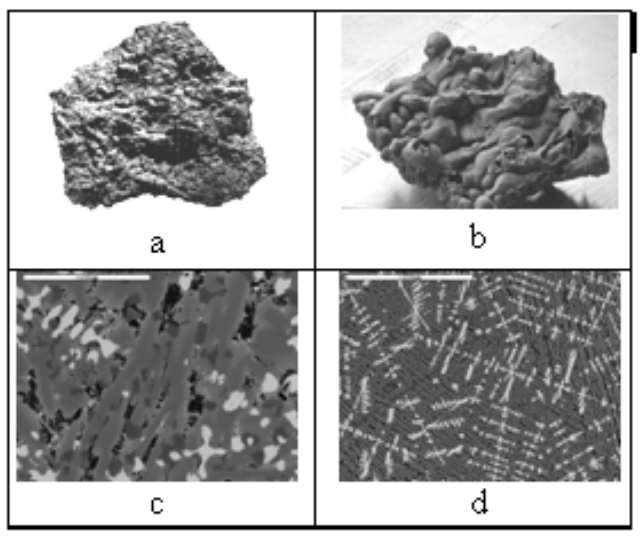

1. ábra.

a. Kemencesalak fotója [3]. b. Folyósalak [4]. c-d.WIRG kisérletileg kohósitott salakminták mikroszerkezete [5]

(c. kemencesalak, d.folyósalak; SEM felvételek)

A bizonyíthatóan a kohósítás során lecsapolt folyósalak minták, illetve a bizonyíthatóan kemencében kihült kemencesalak minták kémiai összetétele alapján is megállapítható néhány jellemző összefüggés, melyek közül talán legfontosabb a salak $\mathrm{FeO} / \mathrm{Fe}_{2} \mathrm{O}_{3}$ aránya.

A vasoxid színvassá történő redukálásának többlépcsős folyamatában az utolsó oxid állapot a $\mathrm{FeO}$ (wüstit), amely $\mathrm{SiO}_{2}$-dal fayalitot alkot $\left(2 \mathrm{FeO} \cdot \mathrm{SiO}_{2}\right)$. A fayalit tiszta állapotban a bucakemencében is már a legrégebbi időkben is elérhető hömérsékleten olvadt, és elfolyt.

A kohósításra jellemző folyósalak minták nagy részében az összetevők mintegy 70-80 \%-a fayalit és wüstit. A kemencesalakok esetében viszont a reoxidált $\mathrm{Fe}_{2} \mathrm{O}_{3}$ (hematit) aránya, a magnetit $\left(\mathrm{FeO} \cdot \mathrm{Fe}_{2} \mathrm{O}_{3}\right)$ ásványi alkotójaként is beszámítva: nagyobb, mint a folyósalakoké (esetenként akár 10-20\%).

A kohósalakok összetételét $\left(\mathrm{C}_{\text {salak }}\right.$ kizárólag a kiindulóanyagok határozzák meg az (1) általános összefüggésnek megfelelöen [2]:

$$
\mathrm{C}_{\text {salak }}=\mathrm{C}\left[\left(\mathrm{O}-\mathrm{R}_{\mathrm{FeO}}\right)+\mathrm{A}+\mathrm{L}+\mathrm{F}-\mathrm{V}\right]
$$

amelyben $\mathrm{C}$ az oxidösszetétel, a szögletes zárójelben levő kifejezés pedig a kohósítás során a salakképzésben valamilyen szerepet játszó egyes résztvevőknek az oxidösszetételhez való százalékos hozzájárulását adja meg: $\mathrm{O}$ az ércben levő redukálatlan oxid komponensekét, $\mathrm{R}$ a redukált oxid komponensekét, $\mathrm{A}$ a hamuét, L a „kohó-kerámiákét” (kemencefal, kemencebélés, olvasztótégely, fúvóka, kifolyócsap, salakgyüjtő), F a fluxét (ömlesztö), végül $\mathrm{V}$ az illékony komponensekét.

A kovácssalakok $\mathrm{Fe}_{2} \mathrm{O}_{3}$-ben gazdagabb kemencesalakok, amelyek összetételében a hamu és a különféle "kohókerámiák" is jelentősen nagyobb hangsúlyt kapnak.

Egyetlen változatlan technológia és recept használata esetében a morfológiailag azonos csoportba sorolható, véletlenszerüen kiválasztott salakminták a mért átlagos kémiai összetételnek megfelelően egy 
klasztert kell alkotnia (egy jól meghatározható középérték körül kell mozognia). A középértéktől való nem túl nagy eltérést a minták heterogén jellegéből adódó mintavételi hibák, és az egyes kohósítási-megmunkálási technológiai ciklusok közötti (külső körülményekből következö) véletlenszerü különbségek okozzák [2].

Az addigitól eltérö, új technológia vagy recept több klaszter kialakulását jelenti, szignifikánsan nagyobb klaszterek közötti összetételbeli eltérésekkel, mint az egyes klasztereken belüliek

A különböző régiókból, különböző lelöhelyekről, vagy akár egy adott lelöhely különböző kontextusaiból származó mintacsoportok között jelentkező jelentősen eltérő összetételü csoportok (klaszterek) megjelenésének többféle oka lehet. Jelentheti máshonnan származó vasérc vagy tüzelö, ömlesztő használatát [6], lehet szó eltérő bucakemence konstrukcióról és kohósítási paraméterekről, egy salakminta együttesen belül pedig az idők során a kohósítás körülményei mellett változhatott a kohósítási recept is [7].

A kísérleti eredmények (az egyes klaszterek és a hozzájuk rendelhető paraméterek) értelmezése tehát esetenként más és más, a csoportok sokváltozós szerkezetétől és az alkalmazott statisztikai eljárástól függően.

\section{Következtetések}

A vas kémiai reakcióképessége következtében a megfelelően azonosított vassalak maradványok adatszolgáltatóként kikerülhetetlenek mind a vasgyártás és vasmüvesség folyamatainak fizikai-kémiai és metallurgiai aspektusainak, mind a vasleletek származásának jellemzése szempontjából.

Az azonos kontextusból származó, régészeti sztratigráfiai szempontból koherens, adott kronológiai indikátorokkal jellemezhetö vassalak maradványok feltehetően egyazon vasmüves rendszer azonos korú és származású leletei. Az egyes leletegyütteseken belül azonban mindig tapasztalhatók kisebb-nagyobb eltérések, hiszen a minták származhatnak egy vagy több technológiai ciklus különböző szakaszaiból, a salakok szerkezete és összetétele heterogén, és különbözhetnek az egyes termelési ciklusok körülményei (akár a gyártási recept és eljárás is).

A salakleletek helyes tipizálásának tehát nagy a jelentősége a technológiára, provenanciára vonatkozó megbízható régészeti következtetések szempontjából.

\section{Köszönetnyilvánítás}

A jelen kutatás az EME-450/8/1/P.2/2014 projekt keretében valósult meg.

\section{Szakirodalmi hivatkozások}

[1] Török B.: Árpád-kori vaskohászati mühelyek metallurgiája a müszaki vizsgálatok tükrében, Gesta IX, 2010, 227-232.

[2] Charlton, M.F. és mások: Measuring variation in iron smelting slags: an empirical evaluation of group-identification procedures, in "The World of Iron", Humphris, J., Rehren, Th., (szerk.), Archetype Publications, London, ISBN: 9781904982975, 2013, 421-430.

[3] Friede, H. M. és mások: Archaeometallurgical studies of iron smelting slags from prehistoric sites in Southern Africa, Journal of the South African Institute of Mining and Metallurgy, 82 (2), 1982, 38-48.

[4] Howard, A., és mások: The evolution of arms and armors during the Crusades, Project Report, Worcester Polytehnic Institute, 2013, 19.

[5] www.wealdeniron.org.uk

[6] Buchwald, V. F., Wivel, H.: Slag analysis as a method for the characterization and provenancing of ancient iron objects, Materials Characterization, 40, 1998, 73-96.

[7] Charlton, M.F. és mások: Explaining the evolution of ironmaking recipes - an example from northwest Wales, Journal of Anthropological Archaeology, 29, 2010, 352-367. 